\title{
Cost Efficiency of Cryopreservation as a Long-Term Conservation Method for Coffee Genetic Resources
}

\author{
M. E. Dulloo,` A. W. Ebert, S. Dussert, E. Gotor, C. Astorga, N. Vasquez, J. J. Rakotomalala, \\ A. Rabemiafara, M. Eira, B. Bellachew, C. Omondi, F. Engelmann, F. Anthony, J. Watts, Z. Qamar, and L. Snook
}

\begin{abstract}
Coffee (Coffea spp.) is one of the world's most valuable agricultural export commodities produced by small-scale farmers. Its germplasm, which holds useful traits for crop improvement, has traditionally been conserved in field genebanks, which presents many challenges for conservation. New techniques of in vitro and cryopreservation have been developed to improve the long-term conservation of coffee. But a question remains as to whether these new techniques are more cost effective than field collections and more efficient at reducing genetic erosion. This study compared the costs of maintaining one of the world's largest coffee field collections with those of establishing a coffee cryo-collection at the Centro Agronómico Tropical de Investigación y Enseñanza (CATIE) in Costa Rica. The results indicate that cryopreservation costs less (in perpetuity per accession) than conservation in field genebanks. A comparative analysis of the costs of both methods showed that the more accessions there are in cryopreservation storage, the lower the peraccession cost. In addition to cost, the study examined the advantages of cryopreservation over field collection and showed that for species that are difficult to conserve using seeds, and that can only be conserved as live plants, cryopreservation may be the method of choice for long-term conservation of genetic diversity.
\end{abstract}

M.E. Dulloo, E. Gotor, F. Engelmann, J. Watts, and L. Snook, Bioversity International, via dei Tre Denari 472/a, 00057 Maccarese, Rome, Italy; A.W. Ebert, C. Astorga, and N. Vasquez, Centro Agronómico Tropical de Investigación y Enseñanza, Apartado Postal 01-7170, Turrialba, Cartago, Costa Rica; S. Dussert, F. Engelmann, and F. Anthony, Institut de Recherche pour le Développement, 911 Av. d'Agropolis, BP 64501 F34394, Montpellier, France; J.J. Rakotomalala, and A. Rabemiafara, Centre National de la Recherche Appliquée au Développement Rural, BP. 1690 Ampandrianomby, 101 Antananarivo, Madagascar; M. Eira, Embrapa coffee/Embrapa Genetic Resources and Biotechnology, av W3 Norte, final PqEB, 70770-901 Brasilia DF, Brazil; B. Bellachew, Ethiopian Institute of Agriculture Research, Jimma Agricultural Research Centre, P.O. Box 192 Jimma, Ethiopia; C. Omondi, Coffee Research Foundation, P.O. Box 4 Ruiru, Kenya; Z. Qamar, Food and Agriculture Organization of the United Nations, Viale Terme di Caracalla, 00100, Rome, Italy; A.W. Ebert, currently at Genetic Resources and Seed Unit, AVRDC- The World Vegetable Center, P.O. Box 42, Shanhua, Tainan, 74199 Taiwan. Received 29 Dec. 2008. *Corresponding author (e.dulloo@cgiar.org).

\begin{abstract}
Abbreviations: CATIE, Centro Agronómico Tropical de Investigación y Enseñanza, Costa Rica; CIR AD, Centre de Coopération Internationale en Recherche Agronomique pour le Développement, France; FAO, Food and Agriculture Organization of the United Nations; Incaper, Instituto Capixaba de Pesquisa, Assistência Técnica e Extensão Rural, Brazil; IRD, Institut de Recherche pour le Développement, France; JARC, Jimma Agricultural Research Center, Ethiopia; LN, liquid nitrogen; ORSTOM, Organisation de Recherche Scientifique et Technique Outre Mers, France; UNCED, United Nations Conference on Environment and Development.
\end{abstract}

W HILE THE WORLD'S CONSUMERS are happily enjoying their daily cups of coffee (Coffea spp.), coffee genetic resources, which form the basis for improved coffee production and quality, are rapidly becoming less diverse. Coffee is not only one of

Published in Crop Sci. 49:2123-2138 (2009).

doi: 10.2135/cropsci2008.12.0736

(C) Crop Science Society of America

677 S. Segoe Rd., Madison, WI 53711 USA

All rights reserved. No part of this periodical may be reproduced or transmitted in any form or by any means, electronic or mechanical, including photocopying, recording, or any information storage and retrieval system, without permission in writing from the publisher. Permission for printing and for reprinting the material contained herein has been obtained by the publisher. 
the most popular beverages in the world, but it is also the world's most valuable agricultural export commodity, with a annual export value of US $\$ 6.2$ billion in 2007 (ICO, 2008). Most coffee is produced in the developing world, and unlike other commodities, coffee is grown predominantly by small-scale farmers, many of whom are resource poor; the coffee trade is vital for their livelihoods.

The coffee industry's success depends on the availability of diversity to enhance the genetic base of the crop and provide resistance to pests and diseases such as coffee berry disease (caused by Colletotrichum kahawae Waller and Bridge), coffee rust (caused by Hemileia vastatrix Berk. and Br.), Fusarium wilt [caused by Fusarium oxysporum Schl. f. sp. Coffea (Garcia) Wellman], bacterial blight [caused by Pseudomonas syringae pv garcae (Amaral et al) Young et al. 1978], nematodes, and major insect pests. Genetic diversity also facilitates adaptation to abiotic stresses such as drought and allows for enhancement of qualities like aroma and flavor. The precise sources of these traits and resistance to these pests and diseases are still being sought and identified. For these reasons, genetic resources are of great value to breeding programs. Hein and Gatzweiler (2006) assessed the value of $C$. arabica $\mathrm{L}$. genetic resources in the Ethiopian highlands for breeding and obtained net values for coffee genetic resources of US $\$ 1.4$ billion and US $\$ 420$ million, at discounted rates of 5 and 10\%, respectively, based on a 30-yr discounting period. For an overview of historical and new trends in coffee breeding, see the work of Vega et al. (2008).

Much coffee genetic diversity is still found in the wild. The forests of West and Central Africa, southwestern Ethiopia, and neighboring countries are the centers of origin of cultivated Coffea species, while the forests of Madagascar are home to the relatively isolated Mascarocoffea section of the genus, which is characterized by low-or even no-caffeine (Dulloo, 1998). Aside from farmers growing traditional coffee varieties in their fields, these forests are the ultimate sources of coffee genetic diversity. But deforestation, encroachment of agricultural activities, population pressures, and economic hardship are threatening these reservoirs of genetic diversity (Gole et al., 2002).

Concern for the loss of coffee genetic diversity has stimulated a series of collecting missions by the Food and Agricultural Organization of the United Nations (FAO), the Organization de Recherche Scientifique et Technique Outre Mers (ORSTOM) (now the Institut de Recherche pour le Développement [IRD]), the Centre de Coopération Internationale en Recherche Agronomique pour le Développement (CIRAD), and the International Board for Plant Genetic Resources (now Bioversity International) (Meyer et al., 1968; Guillaumet and Hallé, 1978). Coffee, like many other important species of tropical origin, cannot be conserved as seed using conventional methods of drying and low-temperature storage because its seeds are recalcitrant (Ellis et al., 1990; Hong and Ellis, 1995). Until the recent development of cryopreservation and other methods, coffee could only be conserved in field genebanks, in situ, or on farm. Field coffee collections have been established in Ethiopia, Côte d'Ivoire, Cameroon, Kenya, and Madagascar (Berthaud and Charrier, 1988; Dulloo et al., 2001), which holds the world's largest collection of Mascarocoffea species, including 56 botanical species and 57 undescribed populations (Dulloo et al., 2001).

Collections have also been established in other regions where coffee is an important commodity. In the Americas, collections (of mainly arabica) have been established in Costa Rica, Colombia, and Brazil, while in Asia, Indonesia and India hold important collections (see Table 2). There are also a number of small collections of Coffea germplasm intended mainly for short-term storage in Portugal, France, Germany (Frison and Serwinski, 1995), Peru, Rwanda, the Democratic Republic of the Congo, and Hawaii in the United States (Bettencourt and Konopka, 1988). FAO (1998) estimates that 21,087 coffee accessions are conserved worldwide.

Field collections can be advantageous for characterization, evaluation, identification, and distribution (Reed et al., 2004), but they are far from an optimal conservation method (Dulloo et al., 2001). Many field collections are vulnerable to technical and economic factors, and the genetic diversity they maintain is being lost at a considerable rate. Various authors (Reed et al., 2004; Dulloo et al., 1998; Hawkes et al., 2001; Engelmann and Engels 2002) have underlined the disadvantages of field collections, including the limited extent of genetic diversity that can be conserved in them, the high risk of germplasm loss from pests and diseases, vulnerability to weather and other external risks such as fire, high maintenance costs and space and time requirements, and labor intensiveness. An additional problem associated with field collections is the risk of disease transfer through germplasm exchange.

These problems are not unique to coffee and apply equally to other species held in field genebanks such as banana (Musa acuminata Colla), coconut (Cocos nucifera L.), tropical fruit trees, cacao (Theobroma cacao L.) and other vegetatively propagated species. Thus the risk of heavy losses of diversity in field collections is of major concern. R. Swennen and B. Panis (personal communication, 2008) report that 5 to $10 \%$ of accessions in Musa field collections are lost each year. Such losses can be swift and catastrophic, with a single event precipitating a major depletion of resources. For example, Togo lost its entire yam (Dioscorea spp.) field collection in a fire in 2000 ( $\mathrm{R}$. Vodouhe, personal communication, 2000).

Bioversity International, the world's largest organization dedicated to the conservation of agricultural biodiversity, has long recognized the problems associated with crops that cannot be conserved using conventional methods and has been investing in efforts to develop novel conservation technologies. This research has been accelerated 
by the development of biotechnology. In vitro slowgrowth conservation methods have been cited as good ways of complementing and providing backup to field collections (Dulloo, 1998; Engelmann, 1991). An in vitro slow-growth method has been developed for short-term conservation of coffee (Dussert et al., 1997c) and an in vitro coffee core collection that is genetically representative of the large field genebank in Côte d'Ivoire was set up at IRD in France. However, Dussert et al. (1997a) showed that while some genetic groups were well adapted to in vitro conditions and could be maintained for three years, other genetic groups could not be conserved in vitro and were rapidly lost. This resulted in genetic drift of the in vitro coffee core collection, which indicates that in vitro conservation is not a viable option for conserving coffee genetic resources. Cryopreservation, in which living tissues are conserved at very low temperatures $\left(-196^{\circ} \mathrm{C}\right)$ in liquid nitrogen (LN) to arrest mitotic and metabolic activities, provides a more promising option (Engelmann and Engels, 2002). Plant material can be cryopreserved without alteration or modification for a theoretically unlimited period of time. In addition, cultures are stored in a small volume of space, are protected from contamination, and require only limited maintenance (Engelmann, 1997).

Research on cryopreservation has led to the development of protocols for conserving more than 200 plant species, including Musa, coffee, and citrus (Citrus spp.) (Engelmann and Takagi, 2000; Engelmann, 2004). IRD has performed a number of studies to investigate whether C. arabica seeds are sensitive to LN storage (Dussert et al., 1997b, 1998, 2000, 2001, 2003a). These efforts have led to the development of a successful cryopreservation procedure (Dussert and Engelmann, 2006), which was applied to a core subset of the Centro Agronómico Tropical de Investigación y Enseñanza (CATIE), Costa Rica, coffee collection (Vásquez et al., 2005).

According to the Convention on Biological Diversity, countries have the obligation to ensure both in situ and ex situ conservation of the genetic resources under their sovereignty (Articles 8 and 9) (UNCED, 1992). Other global initiatives such as the Global Strategy for Plant Conservation and the International Treaty on Plant Genetic Resources for Food and Agriculture recommend the establishment of complementary ex situ measures in countries of origin. Since the original diversity of coffee germplasm is in Africa, African countries have the principal burden of ensuring long-term conservation. Alternative ex situ conservation technologies must be suitable to the African context by being low-cost (or at least not cost prohibitive as compared to other methods) and easily implemented with the technological capacity available on the continent.

Bioversity International performed a survey of genebank managers and cryopreservation specialists in 2006 to assess their perspectives on the potential advantages of cryopreservation and obstacles to more widespread adoption. Potential advantages reported by respondents included reduced losses from pests, diseases, and natural disasters that threaten field collections, greater genetic integrity and facilitated use of germplasm, since accessions are more easily replicated and transferred as in vitro materials. Respondents identified lack of trained personnel, lack of protocols, and high establishment and maintenance costs as obstacles to more widespread adoption of cryopreservation. Although the survey results indicated that specialists believe cryopreservation to be expensive, few studies have analyzed the actual costs and effectiveness of cryopreservation or have compared these costs to those of maintaining field genebanks.

Hummer and Reed (1999) calculated the cost of establishing a cryo-collection of temperate fruit trees maintained at the National Clonal Germplasm Repository of the USDA-ARS in Corvallis, OR, at US $\$ 50$ to US $\$ 75$ per accession (not including labor costs) and approximately US \$1 per accession for annual upkeep. Several authors (Jarret and Florkowski, 1990; Epperson et al., 1997; Burstin et al., 1997; Pardey et al., 2001; Saxena et al., 2002; Virchow, 1999, 2003) have documented the conservation costs of a wide range of crops (including sweet potato [Ipomoea batatas L.], cassava [Manihot esculenta Crantz], rice [Oryza sativa L.], maize [Zea mays L.], and wheat [Triticum aestivum L.]) on farm, in vitro, and in seed genebanks. Reed et al. (2004) concluded that the relative costs of field and in vitro collections are quite similar, but that as collections increase in size, in vitro conservation becomes a more economical option.

Respondents to Bioversity's 2006 survey indicated that cryopreservation offers a more secure option than field collections in terms of protecting genetic diversity. However, few in-depth studies of losses from field genebanks have been conducted, and no studies have specifically analyzed coffee germplasm losses in field genebanks. While cryopreservation is presumed to be an effective alternative for conserving coffee germplasm, providing more security and little (if any) loss once accessions are cryopreserved, this hypothesis has not been thoroughly tested in a developing-country genebank.

The current study aims to demonstrate the effectiveness of cryopreservation as an alternative or complement to field conservation. The study specifically addresses two major questions:

1. What are the real threats to and losses of coffee germplasm in the coffee field genebanks around the world?

2 . How do the costs of cryopreservation compare with those of maintaining coffee field collections for longterm conservation?

\section{MATERIALS AND METHODS Case Study}

The coffee collection held by CATIE in Turrialba, Costa Rica, was used as a case study for studying the potential of 
cryopreservation as a complement to field collection. CATIE manages one of the largest field collections of $C$. arabica in the world. First established in 1949, it currently holds 1992 accessions, which are maintained as live plants over approximately 9 ha. The history and sources of introduced accessions in CATIE's collection were documented by Anthony et al. (2007). Between 1999 and 2000, research staff at IRD and CATIE developed and optimized a cryopreservation protocol for coffee seeds with financial support from Bioversity. It was first applied to a subset of the CATIE coffee core collection comprising 63 genotypes, which had been conserved under field conditions; it was the first coffee cryo-bank in the world (Dussert et al., 1997b, 1998, 2000, 2001, 2003a; Vásquez et al., 2005). This provided the ideal case for the present study because the costs of cryopreservation and field collection could be compared at the same location.

\section{Data Collection}

Data from other major coffee collections in Ethiopia, Kenya, Madagascar, Brazil, France, and the United States were collected for comparison, using a simple questionnaire that helped to ensure comparability and quality of data. The questionnaires elicited information about number of accessions conserved over time, number of accessions lost over time (and causes of the loss), and number of individuals per accession. Data were also collected on the costs of field-and cryopreservation, genebank establishment, and annual maintenance (including field preparation and plantation, health management, weeding, fertilizer application, irrigation, and labor). Table 1 lists the institutions participating in the study, their locations, and the types of collections they hold. Follow-up contacts were made with each respondent via email or telephone to clarify responses or request supplementary data. Data on the status of the world's major coffee collections were obtained from published literature and individual contacts with the collection holders (see Table 2).

Table 1. Institutions participating in the study.

\begin{tabular}{|c|c|c|}
\hline Institution & $\begin{array}{c}\text { Type of collection and } \\
\text { species }\end{array}$ & Location \\
\hline $\begin{array}{l}\text { Centro Agronómico Tropical } \\
\text { de Investigación y Enseñanza } \\
\text { (CATIE) }\end{array}$ & $\begin{array}{l}\text { Field collection coffee } \\
\text { C. arabica and C. cane- } \\
\text { phora, C. liberica wild } \\
\text { African diploid coffee }\end{array}$ & $\begin{array}{l}\text { Turrialba, } \\
\text { Costa Rica }\end{array}$ \\
\hline CATIE & $\begin{array}{l}\text { Cryopreserved core collec- } \\
\text { tion of C. arabica coffee }\end{array}$ & $\begin{array}{l}\text { Turrialba, } \\
\text { Costa Rica }\end{array}$ \\
\hline $\begin{array}{l}\text { Centre National de Recherche } \\
\text { Appliquée au Développement } \\
\text { Rural, Madagascar }\end{array}$ & $\begin{array}{l}\text { Field collection coffee- } \\
\text { wild Mascarocoffea } \\
\text { species }\end{array}$ & $\begin{array}{l}\text { Kianjavato, } \\
\text { Madagascar }\end{array}$ \\
\hline $\begin{array}{l}\text { Instituto Capixaba de } \\
\text { Pesquisa, Assistência } \\
\text { Técnica e Extensão Rural }\end{array}$ & $\begin{array}{l}\text { Field collection coffee } \\
\text { C. canephora }\end{array}$ & $\begin{array}{c}\text { Espírito Santo, } \\
\text { Brasil }\end{array}$ \\
\hline $\begin{array}{l}\text { Embrapa, Genetic Resources } \\
\text { and Biotechnology }\end{array}$ & $\begin{array}{c}\text { Cryopreserved collection } \\
\text { coffee C. arabica }\end{array}$ & $\begin{array}{l}\text { Brasília, DF, } \\
\text { Brasil }\end{array}$ \\
\hline $\begin{array}{l}\text { Instituto Agronômico de } \\
\text { Campinas }\end{array}$ & $\begin{array}{l}\text { Field collection coffee } \\
\text { C. arabica }\end{array}$ & $\begin{array}{l}\text { Campinas, } \\
\text { São Paulo, } \\
\text { Brasil }\end{array}$ \\
\hline Coffee Research Foundation & $\begin{array}{l}\text { Field collection coffee } \\
\text { C. arabica and wild African } \\
\text { diploid coffee }\end{array}$ & Ruiru, Kenya \\
\hline $\begin{array}{l}\text { Jimma Agricultural Research } \\
\text { Centre }\end{array}$ & $\begin{array}{c}\text { Field collection coffee } \\
\text { C. arabica }\end{array}$ & $\begin{array}{l}\text { Jimma, } \\
\text { Ethiopia }\end{array}$ \\
\hline
\end{tabular}

\section{Assessment of Field Collection Losses}

To determine the threats to and losses of germplasm in field genebanks, accession losses were assessed along with the number of individual plants within each accession under study. The number of accessions lost over time and the number of individuals maintained for each accession were documented whenever possible. It is good practice to maintain at least 10 individuals per accession to ensure that each accession adequately represents the genetic variation in the population (Dulloo et al., 2001).

\section{Cost of Coffee Field Collection and Cryo-Collection}

A cost study was conducted within a production economics framework based on a methodology developed by Pardey et al. (2001), in which inputs (labor, equipment, etc.) are used to produce certain outputs (in this case, living plants and stored seeds). Data on the estimated costs of the field collection and cryo-collection were obtained from CATIE and IRD (for the cryopreservation protocol only). These were broadly categorized as "establishment costs" and "post-establishment" or "maintenance costs," which allowed a comparison of

a) the first-year and post-first-year costs within the same collection;

b) establishment costs between the field and cryo-collections; and

c) maintenance costs between the field and cryo-collections.

Costs of items and activities in the collections were not based on a particular year, but were recent approximations, and were therefore not subject to inflationary discrepancies. Maintenance costs included the cost of items incurred annually (staff time, chemicals, etc.) and capital items (major equipment) purchased once; the latter costs were annualized using Eq. [1], which takes into account a theoretical interest rate of $2 \%$ and the service lives of the items.

Equation [1] was used to calculate the annualized user cost $Y$ of an item that costs $X$ dollars, purchased every $n$ years.

$$
Y=\left(\frac{1-a}{1-a^{n}}\right) X
$$

where $Y=$ annualized cost, $a=1 /(1+r), n=$ service life, $r=$ interest rate, and $X=$ cost of item. This allowed the estimation of longterm costs for all items in the collections. A depreciation profile of capital (major equipment) assumes that the capital has lasted until the end of its service life and become unusable after that.

The various cost items in the collections were categorized as follows:

1. Capital costs: For the cryopreservation collection, these included the cost of major durable equipment and buildings such as LN storage tanks, LN transfer vessels, laminar flow cabinets, and laboratory buildings, which not only house the cryo-collection but have many other functions. The cost ascribed to the cryo-collection represents only a fraction of the total cost of the building and is calculated according to the space occupied by the cryo-collection itself. For the field collection, the only capital cost is land. Both land and laboratory space were included in a onetime fixed cost of establishment. For subsequent years, 
Table 2. Status of the world's major coffee (Coffea and Psilanthus) field genebank collections.

\begin{tabular}{|c|c|c|c|c|}
\hline Country & Institute & $\begin{array}{c}\text { No. of } \\
\text { accessions }\end{array}$ & Taxa (no. of accessions in brackets) & Source \\
\hline$\overline{\text { Brazil }}$ & $\begin{array}{l}\text { Instituto Agronômico } \\
\text { de Campinas (IAC) }\end{array}$ & 14,101 & $\begin{array}{l}\text { C. arabica (4000), C. canephora (1000), and other coffee } \\
\text { species including C. brevipes, C. congensis, C. eugenioides, } \\
\text { C. kapakata, C. liberica, C. racemosa, C. salvatrix, C. stenophylla } \\
\text { (14), P. bengalensis (3), other material (84), and hybrids (9000) }\end{array}$ & IAC (unpublished data, 2006) \\
\hline
\end{tabular}

Instituto Capixaba de

Pesquisa, Assistência

Técnica e Extensão

Rural (Incaper)

Instituto Agronômico

do Paraná (IAPAR)

Empresa de Pesquisa

Agropecuária de Minas Gerais (EPAMIG) Cameroon Institut de la Recherche
Agronomique (IRA)

Colombia Centro Nacional de Investigaciones de

Café Pedro Uribe Mejia (CENICAFE)

\section{Costa Rica Centro Agronómico Tropical de Investi- gación y Enseñanza (CATIE)}

Côte d'Ivoire Centre National de la recherché Agronomique

$\begin{array}{lc}\text { Ethiopia } & \begin{array}{c}\text { Jimma Agricultural } \\ \text { Research Center }\end{array} \\ \text { India } & \begin{array}{c}\text { Central Coffee } \\ \text { Research Institute }\end{array} \\ \text { Indonesia } & \begin{array}{c}\text { Indonesian Coffee and } \\ \text { Cocoa Research } \\ \text { Institute (ICCRI) }\end{array} \\ \text { Kenya } & \begin{array}{c}\text { Coffee Research Foun- } \\ \text { dation (CRF) } \\ \text { Madagascar }\end{array} \\ & \text { FOFIFA }\end{array}$

Tanzania Tanzania Agricultural Research Organization

USDA

1804

1992

8003

$$
\text { C. canephora }
$$

Incaper (unpublished data, 2006)

C. arabica (>1000), C. canephora (50), and other coffee species including C. congensis (8), C. eugenioides, C. kapakata, C. liberica, C. racemosa, C. stenophylla, and hybrids (1000)

160 C. arabica (1160), including 200 accessions of Timor Hybrid

C. arabica (1787), C. canephora (811), and other coffee species including C. anthonyi (50), C. brevipes (126), C. charrieriana (10), C. congensis (1598), C. costatifructa (46), C. eugenioides (1000), C. fadenii (4), C. heterocalyx (12), C. humbotiana (182), C. humilis (462), C. kapakata (2), C. liberica var. dewevrei (738), C. liberica var. liberica (253), C. millotii (1), C. perrieri (1), C. pseudozanguebariae (340), C. racemosa (66), C. sakarahae (11), C. salvatrix (44), C. sessiliflora (57), C. stenophylla (216), Coffea sp. (451), P. bengalensis

(3), P. ebracteolatus (22), P. mannii (196), Psilanthus sp. (75)

\section{C. arabica (4646), C. canephora (1), and other coffee} species including $C$. congensis (1), C. eugenoiodes (1), C. kapakata (1), C. racemosa (1), and C. stenophyla (1)

C. arabica (329), C. canephora (240), and other coffee species including $C$. congensis, $C$. eugenioides, $C$. liberica, C. racemosa, C. salvatrix, C. stenophylla, and C. zanguebariae

$$
\text { C. arabica (186), C. canephora (1296), }
$$

and other coffee species and interspecific species (155)

$$
\begin{aligned}
& \text { C. arabica (592), C. eugenioides (28), } \\
& \text { C. zanguebariae (13), Coffea sp. (1) }
\end{aligned}
$$

C. abbayesii (1), C. alleizetti (1), C. andrambovatensis (2), C. ankaranensis (4), C. arenesiana (1), C. augagneuri (3), C. bertrandi (3), C. betamponensis (1), C. boiviniana (7), C. bonnieri (1), C. commersoniana (1), C. coursiana (1), C. dubardi (11), C. eugenioides (1), C. farafanganensis (1), C. heimii (2), C. homollei (3), C. humblotiana (2), C. jumellei (1), C. kianjavatensis (2), C. lancifolia (3), C. mangorensis (3), C. mauritiana (8), C. millotii (6), C. mogenetii (2), C.myrtifolia (2), C. perrieri (8), C. pervilleana (3), C. ratsimamangae (4), C. resinosa (12), C. richardii (4), C. sahafaryensis (3), C. sakarahae(4), C. tetragona (1), C. tsaratananensis (2),

C. tsirananae (2), C. vatovavyensis (3), C. vianneyi (6),

C. vohemarensis (1), Coffea spp. (35), Psilanthus spp. (5)

C. arabica (42), C. canephora (19), and other coffee species including C. congensis (5),C. eugenioides (10), C. kapakata (1), C. liberica (24), C. ligustroides (1), C. mufindiensis (1), C. racemosa

(2), C. salvatrix (1), C. stenophylla (1), C. zanguebariae (1)
IAPAR (unpublished data, 2006)

EPAMIG (unpublished data, 2006)

Bettencourt and Konopka, (1988), FAO (1996)

Bettencourt and Konopka, (1988)$$
\text { ( }
$$

CATIE (unpublished data, 2006)

Anthony (1992), updated according to Davis et al. (2006)

\section{B. Bayetta}

(personal communication, 2008)

Bettencourt and Konopka (1988)

ICCRI (unpublished data, 2006)

\section{Omundi}

(personal communication, 2008)

J.J. Rakotomalala (personal communication, 2008) updated according to Davis et al. (2006)

Bettencourt and Konopka (1988), updated according to Davis et al., 2006

Bettencourt and Konopka (1988) 
the cost of field collection was annualized based on an inflation rate of $2 \%$ over $50 \mathrm{yr}$.

2. Quasi-fixed costs: These costs represent human capital input such as educated or scientific labor (managers/curators). Professionals are normally hired on multiyear contracts and their labor input does not fluctuate with the size of the collection. However, the allocation of labor for various activities in the collection can differ.

3. Variable costs: Variable costs are sensitive to the scale of the collection's operation and include costs of propagation, regeneration, and-in a field collection-low-skilled, unscientific, or seasonal labor. In a cryo-collection facility, these include minor equipment such as lab materials and LN. It is not necessary to calculate regular regeneration costs for long-term conservation of cryo-preserved material, as it is for field collections.

4. In-perpetuity costs: Germplasm conservation is a longterm endeavor that requires a long-term perspective, in spite of the fact that genebanks are normally financed on a short-term basis. These costs, which include the amount required to fund a genebank in perpetuity, are based on the present values of the costs of funding the genebank at the current level at a theoretical discount rate (in this study, 4\%) over the long term.

Annualized user cost values (Eq. [1]) can be used to calculate the present values of costs in perpetuity (Eq. [2]) at theoretical interest rates:

$$
\mathrm{PV}=\left(\frac{1}{1-a}\right) Y
$$

where $\mathrm{PV}=$ present value, $Y=$ annualized cost, $a=1 /(1+r)$ $<1$, and $r=$ interest rate. This equation is used to calculate the present value of a cost in perpetuity of a service costing $X$ dollars purchased every year from time zero.

Using Eq. [1], the present values of a cost $(X)$ incurred were determined for each year at theoretical real rates of interest $(2$, $4,6 \%)$ for a specific time period $(30,50,70,100,150 \mathrm{yr})$ and totaled to provide the present value for that time period.

\section{RESULTS}

\section{Status of Field Coffee Collections}

Figure 1 (a-e) shows the status of the field coffee collections at CATIE (Costa Rica), Kianjavato (Madagascar), Jimma Agricultural Research Centre (JARC) (Ethiopia), the Coffee Research Institute (Kenya), and Instituto Capixaba de Pesquisa, Assistência Técnica e Extensão Rural (Incaper; Brazil) in terms of new accessions acquired since their establishment and the number of accessions lost during the same period.

At CATIE, the accessions introduced in 1949 represent $1.4 \%$ of the total number of conserved accessions. The largest introductions took place between 1951 and 1970, when FAO conducted its principal coffee-collecting missions (Meyer et al., 1968); these constitute 58.3\% of the living accessions in the collection. The acquisition of new accessions decreased during the following decade and increased again between 1981 and 1990, when CATIE received accessions from an ORSTOM collecting mission. Approximately 125 accessions out of 2117 have been lost since the collection's establishment, with most losses occurring between 1990 and the present (Fig. 1a). Losses were caused by (i) age of trees-over $50 \%$ of the accessions were introduced before 1970 and are currently more than 35 years-old (Table 3); (ii) waterlogging - the present site of the field collection is on flat land characterized by irregular patches of cemented soil layers at a depth of 30 to $80 \mathrm{~cm}$; and (iii) a commercial style of collection management, which does not devote sufficient attention to the different requirements of wild genotypes compared to commercial varieties in terms of shade, pruning, and fertilizer application.

Madagascar's coffee collection is unique in that it holds a wide diversity of species, most of which are endemic to the island. Two collections were established in the early 1960s at Kianjavato and Ilaka Est, following collecting missions by the French institutions ORSTOM and CIRAD. Information is available on those accessions introduced from the time of the collections' establishment until 1971 (thereafter, no records are available as many documents were lost when the French left the island during the socialist revolution in 1972). Between 1960 and 1971, 319 accessions were inventoried (254 at Kianjavato and 65 at Ilaka Est). The Kianjavato collection consisted of 6218 trees over an area of 11 ha while the Ilaka Est collection was comprised mostly of accessions from Kianjavato; few accessions at Ilaka were unique. The entire coffee collection at Ilaka Est was lost in a severe tropical cyclone and was completely abandoned in the early 1990s due to lack of budget for its rehabilitation and maintenance.

Madagascar's main collection at Kianjavato has also experienced heavy losses over the years. A complete inventory in 1982 revealed only 196 accessions, indicating a loss of 58 accessions between 1971 and 1982, among them two described species_-Psilanthus bengalensis (Roxb. ex Schult.) J.F. Leroy and C. buxifolia A. Chev. Between 1982 and 1999, another 25 accessions were lost, including a Baracoffea accession. Overall, Madagascar has lost 46\% of its original accessions and $58 \%$ of its total number of trees. A major cause of these losses was nonadaptability of the species or accessions to the soil or climatic conditions at Kianjavato. In addition, between 1982 and 2000, the budget allocated to the maintenance of the living collections was inconsistent - in some years, no maintenance was undertaken at all, resulting in the loss of weak hybrid accessions. Today, the Kianjavato collection contains 3668 individuals representing 173 accessions.

The major coffee field collection in Ethiopia is maintained at JARC and its subcenters at Gera, Haru, Awada, Agaro, and Mechara, which are located in Ethiopia's major coffee-growing areas. Although early collections were set up in the 1950s, the principal coffee collection was established 
following FAO and French collecting missions in the 1960s. Since 1970, there has been a longterm national collecting program in which 50 to 100 accessions have been collected. In 1998 and 2002, more intensive collecting took place in efforts to save the area's coffee germplasm, which was endangered by drought, competition with chat (Khata edulis Forsk) and other threats. More germplasm was added to the collection as accessions were gathered from the highlands of Ethiopia. Presently, the collection contains over 5000 arabica coffee accessions from different coffee-growing areas. Over the period of study, 657 accessions were lost in Ethiopia out of 5279 accessions planted. Reported causes of loss include poor early establishment, root and stem wilt diseases, and problems with adapting plants introduced from another locality to the field genebank.

Introduction of coffee germplasm into Kenya started in the early part of 20th century, but these samples were subsequently discarded as they were poorly adapted to Kenyan growing conditions. The coffee collection was re-established in the early 1960s, with more introductions obtained during a 1964 FAO collecting mission and two ORSTOM collecting missions in 1966 and 1977. The latest collecting mission sought to enrich the collection with indigenous coffee species. Kenya reported a loss of only 50 out of 2557 total accessions, with no reported loss of accessions since 1965. Since 2000 however, there has not been any new introduction of coffee germplasm into Kenya's collection. The losses before 1965 occurred because accessions were removed from the field genebank for demonstration plots and to establish a tissue-culture laboratory.

There are several coffee field collections in Brazil. The principal Coffea genebank located at the Fazenda Santa Elisa at Campinas, São Paulo, is maintained by the Instituto Agronômico de Campinas. Established in 1932, the collection holds 13,900 accessions, 65\% of which are hybrid varieties, and includes 3800 accessions of C. arabica. It also contains 1000 accessions of C. canephora Pierre ex A. Froehner and 14 other Coffea species as well as Psilanthus species. The collection is maintained over an area of 40 ha. A second collection, held by the Incaper and located at the Fazenda Experimental de Marilândia, in Marilândia, Espirito Santo State, is essentially composed of C. canephora clones. The genebank was established in 1985, with new accessions added each year since. Today, it contains 375 accessions with 10 individuals of each accession over an area of 2.2 ha. Another comprehensive coffee field genebank was established in 1974 at the Instituto Agronômico do Paraná in Londrina, Paraná State. This collection contains nearly 3000 accessions of C. arabica (wild material, cultivars, and hybrids), C. canephora, and other Coffea species. A new collection was established in 2003 at the Fazenda Experimental de Patrocínio of the Empresa de Pesquisa Agropecuária de Minas Gerais, with more than 1000 accessions of C. arabica, including 200 accessions of Timor Hybrids (see Table 2). In 2002, a cryo-research collection of Coffea germplasm was also established at Embrapa Genetic Resources and Biotechnology in Brasilia.

Table 3. Genetic erosion estimated by the percentage of dead trees and lost accessions in three areas of the Centro Agronómico Tropical de Investigación y Enseñanza (CATIE) genebank between 1993 and 2002 (from Anthony et al., 2007).

\begin{tabular}{lrccc}
\hline Section & Age & Genetic origin & Dead trees & Lost accessions \\
\cline { 4 - 5 } & $\mathrm{yr}$ & & \multicolumn{2}{c}{$\%$} \\
A & $>45$ & Cultivated & 14.9 & 2.0 \\
C & 40 & Wild & 11.6 & 3.6 \\
F & 20 & Wild & 15.7 & 8.2 \\
\hline
\end{tabular}




\section{Analysis of Genetic Erosion}

The number of trees per accession can be a good indicator of the extent of erosion in a field collection. Information on the structure of the collections was available only for CATIE in Costa Rica and Kianjavato in Madagascar, and is shown in Fig. 2. Accessions maintained in Kianjavato were represented by a varied number of individuals: from one to as many as 156. Between 1982 and 1999, the number of accessions at Kianjavato with more than 10 individuals decreased from 118 to 82 (Table 4 and Fig. 2), while all categories with fewer than 10 individuals increased during this period.

The 2006 inventory at Kianjavato indicated that accessions with more than 10 individuals increased while the other size categories decreased. This was the result of a donor-supported project that funded the replacement of missing individuals to constitute at least 10 per accession. The project has contributed approximately $90 \%$ of the collection's maintenance costs since 2002 .

At CATIE, a detailed analysis of genetic erosion in three areas of the coffee genebank between 1993 and 2002, stratified on the basis of the original source (cultivated or wild) and establishment date of the collection, demonstrated an average of $3.6 \%$ erosion of wild coffee accessions that had been established for $40 \mathrm{yr}$ in one section of the field genebank (Table 3). A higher rate of erosion (8\%) was noted in another section of the field genebank composed of wild coffee accessions that had been established for $20 \mathrm{yr}$.

While degree of erosion can be a function of management, it can also result from the genetic characteristics of the accessions themselves and environmental events such as storms. In the CATIE collection, the erosion rate as indicated by numbers of accessions represented by only one or two trees (the most threatened accessions) increased between 1993 and 2002 (Fig. 2). The situation is different in Madagascar, however, where the number of accessions in the same category (1-2 and 3-4 individuals) increased from 1982 to 1999, but then decreased (Fig. 2). An analysis of the data shows that $52 \%$ of the accessions lost at Kianjavato were represented by less than three trees each. The fact that many trees (up to 156 individuals) were initially collected for each accession (see Fig. 3) ensured their survival, at least among those that could not adapt to Kianjavato's edapho-climatic conditions.

\section{Cost of Field and Cryo-Collections}

Tables 5 and 6 illustrate the total actual costs of the CATIE coffee field collection and cryo-collection required for longterm conservation. These include the first-year one-time fixed cost of establishment and the annual maintenance costs.

These calculations are based on the current number of accessions in the field collection (1992) and the current maximum capacity of the cryopreservation facility (300 accessions). Cost data on cryopreservation are also forecasted for 500, 1000, and 2000 accessions. For the field collection, the establishment cost for 1992 accessions was
US $\$ 138,681$ and the cost of maintaining the collection was US $\$ 30,343$ per year. The costs of the cryopreserved collection amounted to US $\$ 28,377$ for establishment and US $\$ 2400$ per year for maintenance, for 300 accessions. The per-accession costs for the establishment of the field and cryo-collections totaled US\$69.62 and US\$95.00, respectively, and the per-accession costs for maintenance were US $\$ 15.00$ and US $\$ 8.00$, respectively.

It is not possible to directly compare the costs of establishing the field collection with those of the cryocollection because of the different numbers of accessions held in each. However, a projection of the cost of cryocollection for a collection of 500, 1000, and 2000 accessions shows that for cryopreservation, the total costs of an increasing number of accessions increase, while the year 1 and post-year 1 costs for establishment and maintenance per accession decrease due to economies of scale. Figure 4 demonstrates that it is possible to make better use of existing durable equipment and infrastructure with a larger number of accessions preserved.

The total actual costs of the equipment needed for cryopreservation for different numbers of accessions are reported in Table 7 and Fig. 6. As the data indicate, associated costs increase with number of accessions only for some pieces of equipment; the largest price increase is the cost of LN tanks (from US $\$ 5000$ for 300 accessions to US $\$ 25,000$ for 2000 accessions).

Long-term cost projections for a cryo-collection (with 300, 500, 1000, and 2000 accessions) and a field collection with 1992 accessions are presented as in-perpetuity costs at present value, illustrated as total and per-accession maintenance costs at 2, 4, and 6\% (Table 8 and Eq. [2]). At the highest theoretical interest rate (6\%), the in-perpetuity cost at present value of the field collection is US $\$ 534,036$, while the cryo-collection cost stands at US $\$ 42,240$ for 300 accessions, US $\$ 51,920$ for 500 accessions, US $\$ 71,280$ for 1000 accessions, and US $\$ 199,680$ for 2000 accessions. Per accession, the field collection (at a $2 \%$ rate of interest) has an in-perpetuity cost at present value of US $\$ 776$ whereas the cryo-collection has an in-perpetuity cost at present value of US $\$ 408$ per accession for 300 accessions.

The per-accession in-perpetuity cost of the cryo-collection at present value (and at a $2 \%$ discount rate) decreases as the number of accessions stored under cryopreservation increases, reaching US $\$ 153$ per accession for 2000 accessions

Table 4. Size categories of coffee accessions at Kianjavato, Madagascar.

\begin{tabular}{lccc}
\hline \multirow{2}{*}{$\begin{array}{c}\text { Accession size categories } \\
\text { (no. of plants) }\end{array}$} & \multicolumn{3}{c}{ Inventory years } \\
\cline { 2 - 4 } & $\mathbf{1 9 8 2}$ & $\mathbf{1 9 9 9}$ & $\mathbf{2 0 0 6}$ \\
\hline$>10$ & 118 & 82 & 105 \\
$5-10$ & 25 & 36 & 36 \\
$3-4$ & 13 & 18 & 13 \\
$1-2$ & 16 & 22 & 11 \\
\hline
\end{tabular}


preserved. At a $6 \%$ rate of interest, the field collection has a per-accession in-perpetuity cost at present value of US $\$ 268$ while the cryo-collection per-accession in-perpetuity cost is US $\$ 140$ for 300 accessions, US $\$ 105$ for 500 accessions, US $\$ 70$ for 1000 accessions, and US $\$ 53$ for 2000 accessions.

Projected costs were also calculated as present values of costs incurred in future time periods (up to $150 \mathrm{yr}$ ), illustrated as total costs and per-accession costs, for the field collection and the cryo-collection (Table 9 and Eq. [1]) at the three theoretical interest rates. At a $2 \%$ interest rate, the total cost of the field collection for a period of $30 \mathrm{yr}$ is US $\$ 6070$, whereas the costs of a cryo-collection range from US $\$ 1242$ for 300 accessions to US $\$ 4817$ for 2000 accessions. In $150 \mathrm{yr}$ at the same interest rate, the cost of a field collection would be US $\$ 2866$ as compared to US $\$ 2274$ for a 2000 -accession cryo-collection. At a $6 \%$ rate of interest, the cost in $30 \mathrm{yr}$ of a field collection would be US $\$ 9504$, while the cost of a cryo-collection would be US $\$ 7542$ for 2000 accessions (see Table 8).

In $150 \mathrm{yr}$ at the same interest rate, the cost of a field collection would be US\$7851 and the cost of a 2000-accession cryo-collection would be US\$6230. Over $30 \mathrm{yr}$, the peraccession cost at a $2 \%$ interest rate is US\$3 for a field collection and US $\$ 2.40$ for a 2000 -accession cryo-collection. In $150 \mathrm{yr}$ at the same interest rate, the per-accession cost of the field collection would be US $\$ 1.40$ versus US $\$ 1.14$ for a 2000-accession cryo-collection. At a 6\% interest rate for $30 \mathrm{yr}$, the cost of a field collection is US $\$ 5$ and the cost of a 2000 -accession cryo-collection is US $\$ 4$ (see Table 9).

\section{DISCUSSION}

One of the greatest limiting factors to effective management of field genebanks is a lack of financial resources for weeding, irrigation, fertilizer application, pest and disease control, shade management, maintenance of fencing to protect collections, and other maintenance. The extent of genetic erosion in the collections is highly variable from one genebank to another and is dependent on the resources available for maintaining these collections, on the species being conserved and on their origin. Madagascar's collection has been the most heavily affected by genetic erosion, but still has the most diverse collection in terms of species (Table 2). Whereas the Incaper collection in Brazil, with clones of C. canephora, has not lost a single accession since its establishment (because Incaper has access to secure funding, allowing it to maintain the safe standard of at least 10 individuals per accession), Madagascar suffered from a lack of adequate financial resources for long-term (a) Madagascar

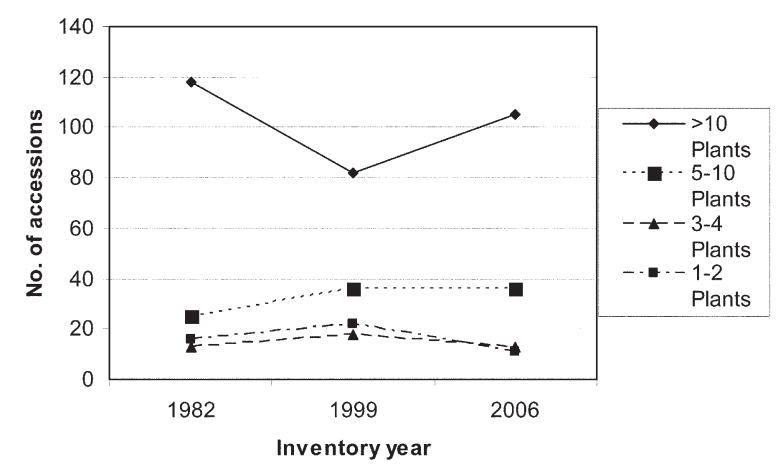

(b) Costa Rica (CATIE)

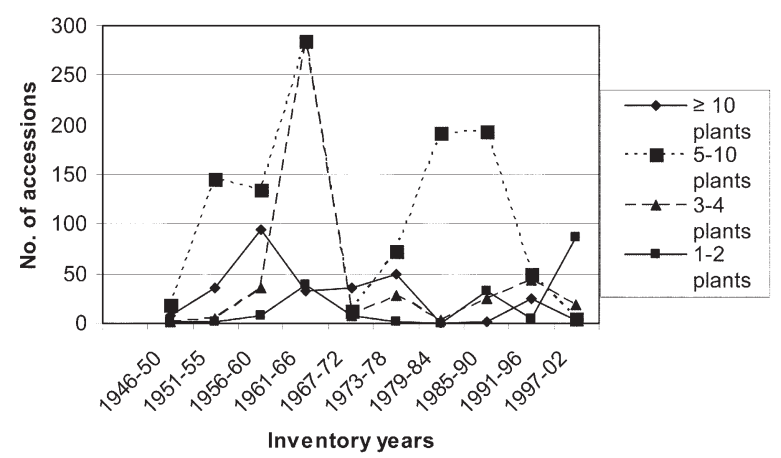

Figure 2. Structure of field coffee collection in (a) Madagascar and (b) Costa Rica.

maintenance. The budget allocated for collection maintenance at Kianjavato was negligible and no maintenance work was performed for several years, leading to genetic erosion. The frequent deaths of individual trees and calls

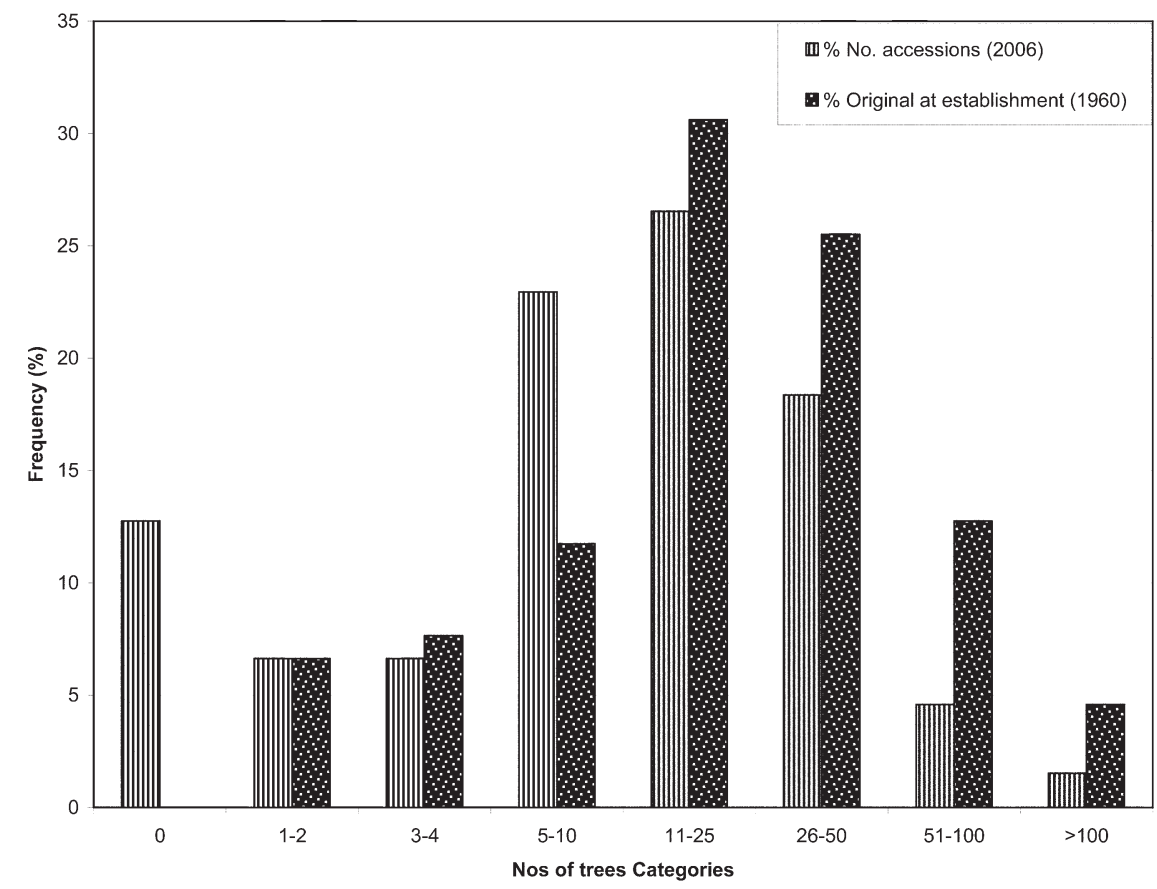

Figure 3. Percentage frequency of number of accessions in different size categories of the Kianjavato collection (Madagascar) in 2006 (striped bars) compared to the original number at establishment in 1960 (dotted bars). 
Table 5. Centro Agronómico Tropical de Investigación y Enseñanza (CATIE) coffee field collection costs (US\$).

\begin{tabular}{|c|c|c|}
\hline Cost period/items & $\begin{array}{c}\text { Cost } \\
\text { category }\end{array}$ & $\begin{array}{l}\text { Cost (US\$), } \\
9 \text { ha }\end{array}$ \\
\hline \multicolumn{3}{|l|}{ First-year (establishment) } \\
\hline Land & $\mathrm{CC}$ & 36,000 \\
\hline Labor for land clearing & VC & 4797 \\
\hline Fencing & $\mathrm{CC}$ & 45,000 \\
\hline Labor for fence establishment & VC & 702 \\
\hline $\begin{array}{l}\text { Land preparation, including shade } \\
\text { establishment }\end{array}$ & VC & 2997 \\
\hline Initial propagation & VC & 999 \\
\hline Nursery materials & VC & 11,250 \\
\hline Shade trees & VC & 90 \\
\hline Labor cost & VC & 4995 \\
\hline Plastic bags & VC & 135 \\
\hline Fertilizer & VC & 225 \\
\hline Fungicides & VC & 225 \\
\hline \multicolumn{3}{|l|}{ Initial field planting } \\
\hline Labor cost & VC & 2502 \\
\hline Fertilizers & VC & 855 \\
\hline Herbicides & VC & 252 \\
\hline Insecticides & VC & 657 \\
\hline Curator & QF & 12,000 \\
\hline Technician & VC & 15,000 \\
\hline Laborer & VC & $\begin{array}{l}\text { Costs included in } \\
\text { operations above }\end{array}$ \\
\hline Total & & 138,681 \\
\hline Cost per accession & & 69.62 \\
\hline \multicolumn{3}{|l|}{ Maintenance cost per year } \\
\hline Curator & QF & 12,000 \\
\hline Technician & VC & 15,000 \\
\hline Laborer & VC & $\begin{array}{l}\text { Costs included in } \\
\text { operations below }\end{array}$ \\
\hline Plant health control & VC & 540 \\
\hline Weeding & VC & 648 \\
\hline Fertilization & VC & 1161 \\
\hline Repair fencing & VC & 486 \\
\hline \multicolumn{3}{|l|}{ Re-establishment } \\
\hline Propagation + field planting & VC & 508 \\
\hline Annualized land cost & VC & 30,343 \\
\hline Total cost per accession (total: 1992) & & 15.23 \\
\hline
\end{tabular}

${ }^{\dagger} \mathrm{CC}$, capital cost; VC, variable cost; $\mathrm{QF}$, quasi-fixed cost.

for continuous regeneration of accessions from other extant individuals added to the cost of maintenance.

Accession loss can also be attributable to natural causes, including tropical cyclones in Madagascar, root-and-stem wilt disease [caused by Gibberella xylarioides R. Heim and Saccas (Fusarium xylarioides Steyaert)] in Ethiopia, and aging of trees and poor drainage at CATIE in Costa Rica. In Ethiopia and Madagascar, losses resulting from inability of plants to adapt to the different conditions in the field genebank were also reported. Events in Madagascar demonstrated that it only takes one catastrophe such as a cyclone to destroy an entire field collection (Ilaka Est).
Staff at CATIE reported that field genebank management (in terms of fertilizer, water, and other inputs) was not customized to the variability within the collection, which resulted in losses. At CATIE, differences in genetic erosion were also attributed to the unique genetic characteristics of the accessions conserved (wild materials). Most of the lost accessions disappeared in the early years after introduction (Bertrand et al., 1993). The greater rate of survival recorded in the oldest plot can be explained by the higher initial number of trees per accession in this part of the genebank (Anthony et al., 2007) and the fact that this plot contained mainly cultivated accessions, which typically adapt more easily to new environments.

Compared with establishing field collections, cryopreservation theoretically offers a more secure means of conservation since there is no loss in germplasm viability during storage. However, losses can occur during the recovery of accessions from cryopreservation. Regeneration trials conducted at CATIE showed a high prevalence of fungal and bacterial infections, which severely affected the survival of the extracted embryos - this shows that the risk of contamination during in vitro culture is high and can lead to loss of plantlets. However, it can be argued that the low rate of recovery is not the result of seed viability loss during cryo-storage, but due to contamination after embryos were introduced in vitro. This highlights the fact that cryopreservation requires highly skilled personnel and needs to be applied with much precision in a sterile environment to prevent contamination.

Experience gained at IRD has shown that slow cooling of seeds using a programmable freezer or a simple bath in dry ice for $25 \mathrm{~min}$, followed by immersion in LN, allows for direct germination of seeds in a greenhouse after rewarming, without the need for in vitro culture (Dussert and Engelmann 2006). Dussert et al. (2003b) developed a probabilistic tool demonstrating that for any accession, a 95\% probability of recovering at least 10 plants (equivalent to 10 trees per accession in a field genebank) with a mean seed survival percentage of $50 \%$, can be obtained from 45 seeds. This cryopreservation protocol developed for coffee seeds yielded a very high rate of recovery (Dussert and Engelmann 2006) and demonstrated that, provided adequate replications of the accessions are made, all accessions can be safely regenerated. Experiments performed in Brazil using a similar cryo-storage protocol for seeds of several Coffea species led to the establishment of 30 C. arabica accessions that were cryopreserved for up to $3 \mathrm{yr}$. Their viability, checked after 2 yr of storage, confirmed that the protocol is valid and that the seeds retained at least $80 \%$ of their initial viability. Seeds of other species such as $C$. racemosa Lour. and C. engenioides S. Moore also survived well following cryopreservation (Eira et al., 2006, 2007).

This study demonstrated that cryopreservation costs less (in perpetuity, per accession) than conservation in field 
Table 6. Centro Agronómico Tropical de Investigación y Enseñanza (CATIE) coffee cryo-collection costs (US\$) for 300, 500, 1000 , and 2000 accessions.

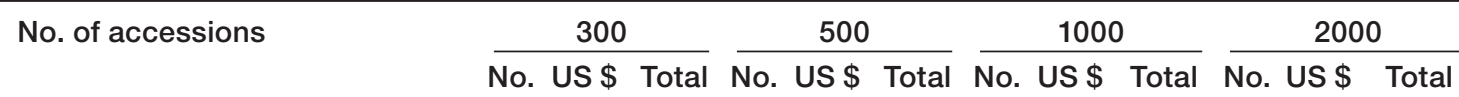

\begin{tabular}{|c|c|c|c|c|c|c|c|c|c|c|c|c|c|}
\hline & Seed handling & & & & & & & & & & & & \\
\hline & Equipment, chemicals, consumables & & & 12,050 & & & 15,010 & & & 21,140 & & & 36,390 \\
\hline & $\begin{array}{l}\text { Transport of all above equipments, } \\
\text { chemicals, consumables }\end{array}$ & & & 3615 & & & 4503 & & & 6342 & & & 10,917 \\
\hline & Custom & & & 3012 & & & 3752 & & & 5285 & & & 9097 \\
\hline \multirow{8}{*}{$\begin{array}{l}\text { Year } 1 \\
\text { (+ final } \\
\text { recovery) }\end{array}$} & Technician, $d$ & 138 & 50 & 6900 & 226 & 50 & 11,300 & 449 & 50 & 22,450 & 897 & 50 & 44,850 \\
\hline & Tank filling & & & & & & & & & & & & \\
\hline & Liquid nitrogen $\left(150 \mathrm{~L} \mathrm{yr}^{-1}\right.$ tank $^{-1}=$ initial filling $\left.+0.3 \mathrm{Ld} \mathrm{d}^{-1}\right)$ & 300 & 5 & 1500 & 450 & 5 & 2250 & 750 & 5 & 3750 & 1500 & 5 & 7500 \\
\hline & Technician, d & 26 & 50 & 1300 & 26 & 50 & 1300 & 26 & 50 & 1300 & 26 & 50 & 1300 \\
\hline & Total & & & 28,377 & & & 38,115 & & & 60,267 & & & 110,055 \\
\hline & Per accession & & & 95 & & & 76 & & & 60 & & & 55 \\
\hline & Tank filling & & & & & & & & & & & & \\
\hline & Technician, d & 26 & 50 & 1300 & 26 & 50 & 1300 & 26 & 50 & 1300 & 26 & 50 & 1300 \\
\hline \multirow[t]{3}{*}{ Post-year 1} & Liquid nitrogen $\left(110 \mathrm{~L} \mathrm{yr}^{-1} \operatorname{tank}^{-1}=0.3 \mathrm{~L} \mathrm{~d}^{-1}\right)$ & 220 & 5 & 1100 & 330 & 5 & 1650 & 550 & 5 & 2750 & 1100 & 5 & 5500 \\
\hline & Total & & & 2400 & & & 2950 & & & 4050 & & & 6800 \\
\hline & Per accession & & & 8 & & & 6 & & & 4 & & & 3 \\
\hline
\end{tabular}

genebanks. The initial cost for the establishment for a cryocollection with 2000 accessions (US $\$ 110,055$ or US $\$ 55$ per accession) is less than that of a field collection with 1992 accessions (US $\$ 138,681$ or US $\$ 69.62$ per accession). These figures are in the same range (US\$50-75) as reported by USDA for its establishment of a cryopreserved temperate fruit collection in Corvallis, OR (Hummer and Reed 1999). However, J.F. Trontin (personal communication,
2007) reported that the establishment of an elm (Ulmus spp.) cryobank in France, which includes 200 bud explants per clone or accession, is €31 per accession-this can be three times more costly than direct establishment of three ramets or clones in the field (integrated, actualized cost over one century). Charrier and Berthaud (1985) calculated the annual cost of establishing and maintaining field collections of Coffea germplasm at Divo (Côte d'Ivoire) to

Table 7. Centro Agronómico Tropical de Investigación y Enseñanza (CATIE) coffee cryo-collection equipment costs (US\$) for $300,500,1000$, and 2000 accessions.

\begin{tabular}{|c|c|c|c|c|c|c|c|c|c|c|c|c|c|c|}
\hline \multicolumn{2}{|r|}{ No. of accessions } & \multirow[b]{2}{*}{ Cost $^{\dagger}$} & \multicolumn{3}{|c|}{300} & \multicolumn{3}{|c|}{500} & \multicolumn{3}{|c|}{1000} & \multicolumn{3}{|c|}{2000} \\
\hline Usage & Item description & & No. & $\begin{array}{l}\text { Unit } \\
\text { price }\end{array}$ & $\begin{array}{l}\text { Total } \\
\text { US\$ }\end{array}$ & No. & $\begin{array}{l}\text { Unit } \\
\text { price }\end{array}$ & $\begin{array}{l}\text { Total } \\
\text { US\$ }\end{array}$ & No. & $\begin{array}{l}\text { Unit } \\
\text { price }\end{array}$ & $\begin{array}{l}\text { Total } \\
\text { US\$ }\end{array}$ & No. & $\begin{array}{l}\text { Unit } \\
\text { price }\end{array}$ & $\begin{array}{l}\text { Total } \\
\text { US\$ }\end{array}$ \\
\hline \multirow{8}{*}{ Drying } & Incubator $\left(27^{\circ} \mathrm{C}, 300 \mathrm{~L}\right)$ & VC & 2 & 1500 & 3000 & 2 & 1500 & 3000 & 2 & 1500 & 3000 & 2 & 1500 & 3000 \\
\hline & Magnetic stirrer & $\mathrm{FC}$ & 1 & 400 & 400 & 1 & 400 & 400 & 1 & 400 & 400 & 1 & 400 & 400 \\
\hline & Balance & $\mathrm{FC}$ & 1 & 300 & 300 & 1 & 300 & 300 & 1 & 300 & 300 & 1 & 300 & 300 \\
\hline & 1-L glass jar with screw cap (100) & VC & 300 & 1 & 300 & 300 & 1 & 300 & 300 & 1 & 300 & 300 & 1 & 300 \\
\hline & $\mathrm{NH}_{4} \cdot 2 \mathrm{SO}_{4}(\mathrm{~kg})$ & $\mathrm{FC}$ & 4 & 25 & 100 & 4 & 25 & 100 & 4 & 25 & 100 & 4 & 25 & 100 \\
\hline & Plasticware (pipettes, vials, etc.) & $\mathrm{FC}$ & 1 & 100 & 100 & 1 & 100 & 100 & 1 & 100 & 100 & 1 & 100 & 100 \\
\hline & Spatula, forceps, etc. & $\mathrm{FC}$ & 1 & 100 & 100 & 1 & 100 & 100 & 1 & 100 & 100 & 1 & 100 & 100 \\
\hline & Glassware (1 bottle $2.5 \mathrm{~L}, 1$ becher, etc.) & $\mathrm{FC}$ & 1 & 100 & 100 & 1 & 100 & 100 & 1 & 100 & 100 & 1 & 100 & 100 \\
\hline \multirow{4}{*}{ Pre-cooling } & Dry ice machine & $\mathrm{FC}$ & 1 & 400 & 400 & 1 & 400 & 400 & 1 & 400 & 400 & 1 & 400 & 400 \\
\hline & $\begin{array}{c}\mathrm{CO}_{2} \text { cylinder } \\
\text { (25 kg liquid } \mathrm{CO}_{2}=6 \times 500 \mathrm{~g} \text { dry ice) }\end{array}$ & VC & 3 & 80 & 240 & 5 & 80 & 400 & 9 & 80 & 720 & 17 & 80 & 1360 \\
\hline & cryovials 5 mL (×500) & VC & 2 & 100 & 200 & 3 & 100 & 300 & 6 & 100 & 600 & 12 & 100 & 1200 \\
\hline & cryocanes (x12) & VC & 25 & 10 & 250 & 42 & 10 & 420 & 84 & 10 & 840 & 167 & 10 & 1670 \\
\hline \multirow{2}{*}{ Cryo-banking } & $\begin{array}{c}\text { 40-L LN tank (10 canisters } \times \\
20 \text { cryocanes }=200 \text { cryocanes) }\end{array}$ & FC & 2 & 2500 & 5000 & 3 & 2500 & 7500 & 5 & 2500 & 12,500 & 10 & 2500 & 25,000 \\
\hline & 25-L transport tank & VC & 1 & 500 & 500 & 1 & 500 & 500 & 1 & 500 & 500 & 2 & 500 & 1000 \\
\hline Thawing & Water bath & $\mathrm{FC}$ & 1 & 700 & 700 & 1 & 700 & 700 & 1 & 700 & 700 & 1 & 700 & 700 \\
\hline Germination & Magenta GA7 Vessels (100 units) & $\mathrm{FC}$ & 1 & 300 & 300 & 1 & 300 & 300 & 1 & 300 & 300 & 1 & 300 & 300 \\
\hline Regeneration & Vermiculite (50 L) & VC & 4 & 15 & 60 & 6 & 15 & 90 & 12 & 15 & 180 & 24 & 15 & 360 \\
\hline Total equipment & & & & & 12,050 & & & 15,010 & & & 21,140 & & & 36,390 \\
\hline
\end{tabular}

tVC, variable cost; FC fixed cost. 
Total Cost

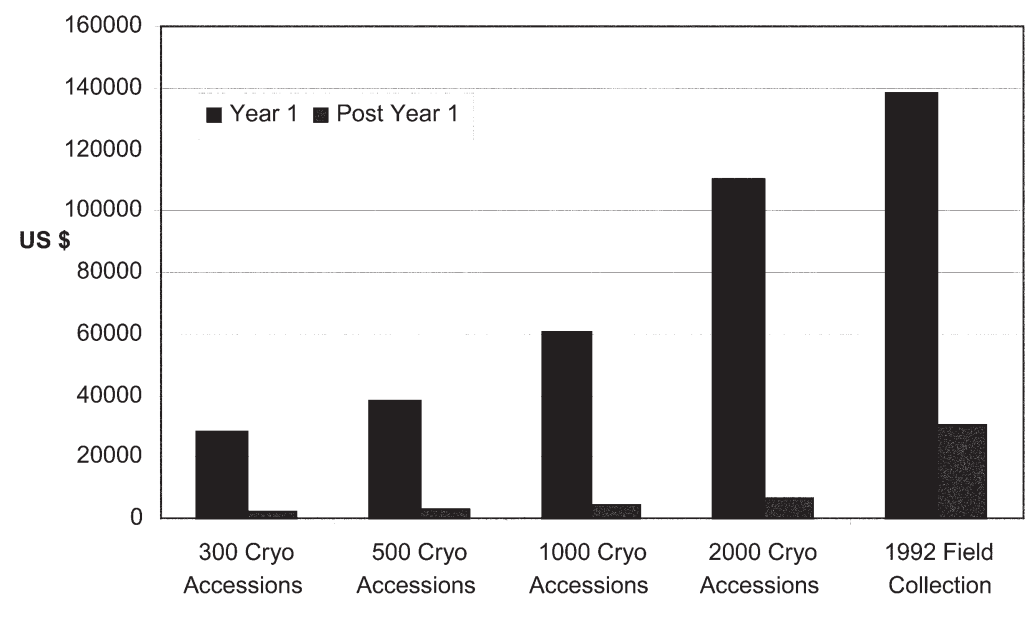

Number of Accessions

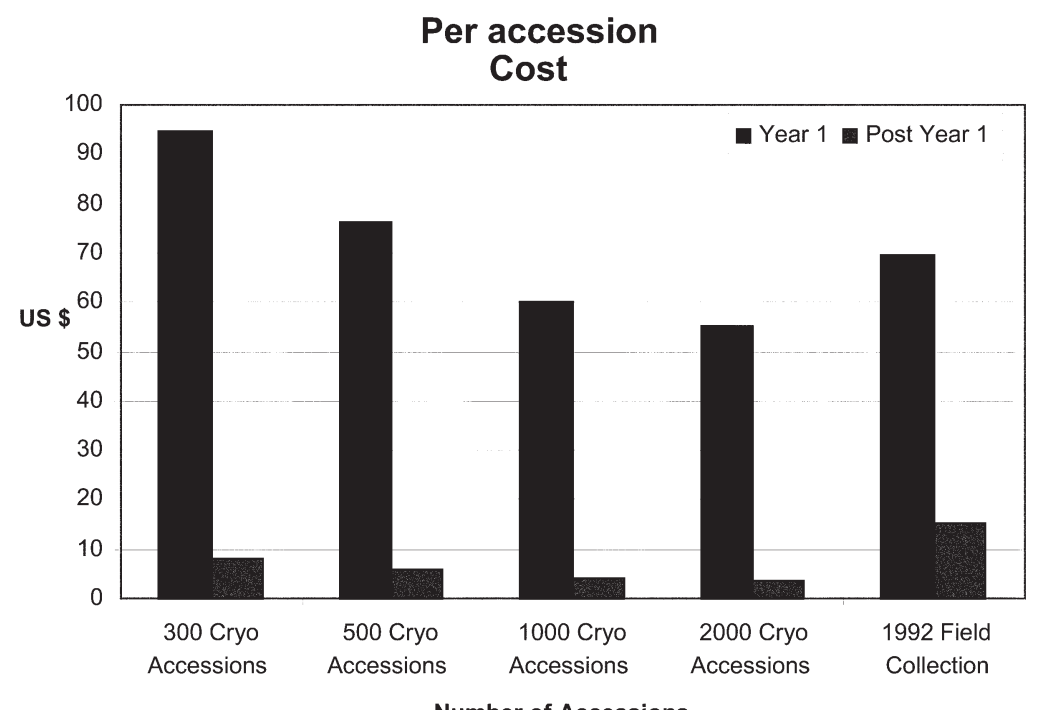

Figure 4. Centro Agronómico Tropical de Investigación y Enseñanza (CATIE) coffee field and cryo-collections total and per-accession cost (US\$).

\section{Costs Per Accessions}

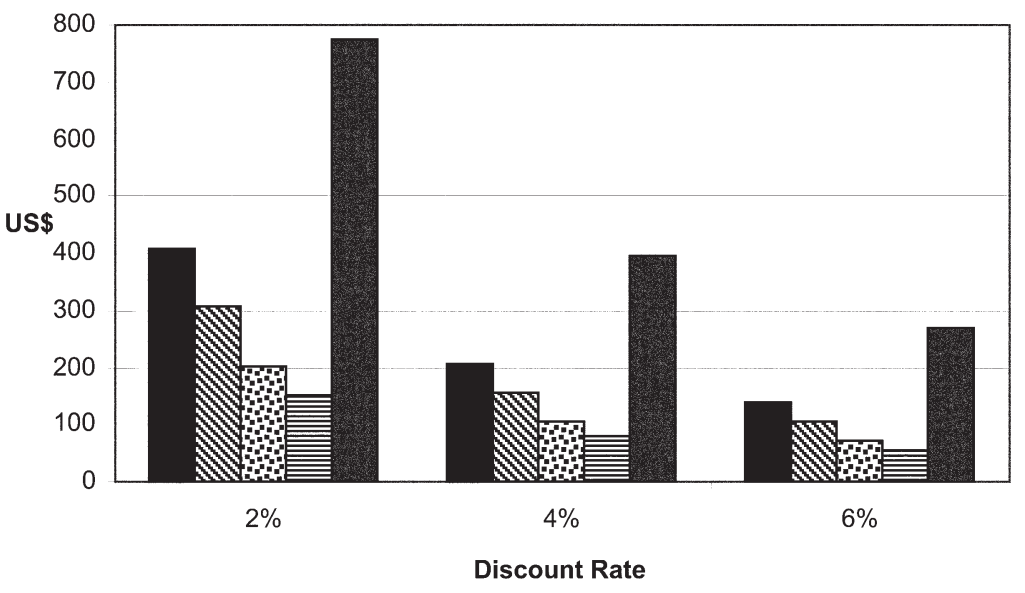

口 300 日 500 田 1000 目 2000 圆 1992 in Field Accessions

Figure 5. Cost per accession in different size cryo-collections; cost of field collection of 1992 accessions shown for comparison. be approximately US $\$ 80$ per genotype, representing $25 \%$ of the total budget of the coffee genetic resources program in Côte d'Ivoire over a period of $20 \mathrm{yr}$.

A comparative analysis of the costs of cryopreservation and field genebanks showed that there are economies of scale associated with cryopreservation, since the more accessions there are in cryopreservation storage, the lower the per-accession cost (Fig. 5).

The current CATIE cryo-collection, with 63 coffee accessions, is not cost effective-the cost per accession for maintaining this collection is US $\$ 95$ (calculated based on 300 accessions). However, if the size of the collection was increased to 2000 accessions, the establishment cost per accession would be reduced to US $\$ 55$, while the annual maintenance cost per accession would be US $\$ 3$. The most significant cost increase, as shown in Table 7 and Fig. 6 (excluding labor cost), would be the capital cost of purchasing additional LN storage tanks. In fact, while only two tanks are needed for 300 accessions, 10 tanks are needed for 2000 accessions, for a total cost of US $\$ 25,000$.

It must be noted that although costs of capital, small equipment, and material in the cryo-collection are annualized, the actual purchasing of equipment spans many years. In addition, these costs do not include any regular regeneration of cryo-preserved material for use, which is not required for long-term conservation. By contrast, in a field collection, significantly higher maintenance costs are incurred perpetually on an annual basis, including frequent regeneration of the field material to prevent loss of accessions due to senescence and other factors. Cost dynamics, therefore, differ over time between the two types of collections. Field collections require higher investments more immediately and in shorter periods of time to sustain themselves, which makes them vulnerable to losses if financing for annual maintenance is unavailable for one or more years, as was the case in Madagascar. This can be especially serious when field collections hold rare or endangered germplasm, where losses caused by sporadic and insufficient financing can lead to extinction. The lower annual maintenance cost of cryo-collections, along with the longer intervals between required capital expenditures, make this conservation technique less vulnerable to the funding cuts and inconsistencies that are a reality of the environment within which many genebanks operate today.

In terms of total costs, cryo-collections can yield greater savings compared to field collections for longterm conservation. The costs of conservation depend on the type of operation-some accrue costs annually (storage) while others incur costs periodically. In 
Table 8. Field and cryo-collections, total and per-accession maintenance costs (US\$), in perpetuity.

\begin{tabular}{|c|c|c|c|c|c|c|}
\hline \multicolumn{2}{|c|}{ No. of accessions } & \multirow{2}{*}{1992} & \multicolumn{3}{|c|}{$-2 \%$} & \multirow{2}{*}{2000} \\
\hline 1ve. Ui ac & & & 300 & 500 & 1000 & \\
\hline \multirow{2}{*}{ Cryo-collection } & Total cost & & 122,400 & 150,450 & 206,550 & 346,800 \\
\hline & Per accession & & 408 & 306 & 204 & 153 \\
\hline \multirow{2}{*}{ Field collection } & Total cost & $1,547,493$ & & & & \\
\hline & Per accession & 776.73 & & & & \\
\hline \multicolumn{2}{|c|}{ No. of accessions } & 1992 & 300 & 500 & 1000 & 2000 \\
\hline \multirow{2}{*}{ Cryo-collection } & Total cost & & 62,400 & 76,700 & 105,300 & 176,800 \\
\hline & Per accession & & 208 & 156 & 104 & 78 \\
\hline \multirow{2}{*}{ Field collection } & Total cost & 788918 & & & & \\
\hline & Per accession & 395.98 & & & & \\
\hline \multicolumn{2}{|c|}{ No. of accessions } & 1992 & 300 & 500 & 1000 & 2000 \\
\hline \multirow{2}{*}{ Cryo-collection } & Total cost & & 42,240 & 51,920 & 71,280 & 119,680 \\
\hline & Per accession & & 140.8 & 105.6 & 70.4 & 52.8 \\
\hline \multirow{2}{*}{ Field collection } & Total cost & $53,4036.8$ & & & & \\
\hline & Per accession & 268.048 & & & & \\
\hline
\end{tabular}

addition, conservation costs depend on type of crop being conserved, the conservation methodology used, the institution, local climate, and the general state of infrastructure available to the genebank (electricity supplies, communications, etc.). Annual and long-term estimates are sensitive to other factors such as crop composition, size of holdings, number of samples distributed annually from genebanks, the rate of interest used to calculate the present value of future costs, and the conservation protocol (especially the frequency with which aging seed samples are tested for viability and regenerated) (Koo et al., 2002, 2003).

In addition to cost, cryopreservation has many other advantages over field collection. It can be regarded as a clean, environmentally friendly technology. Other than LN, a natural product, it does not use any pesticides or fertilizers (pests and diseases cannot survive in the cryo-tank if protocols are followed properly). The space required for cryopreservation is much smaller than that required for a field genebank. As illustrated in the current study, the conservation of 1992 coffee accessions in the field required 9 ha of land while the same number of accessions could be cryo-preserved within $10 \mathrm{~m}^{2}$. The number of genotypes that a field genebank can hold is also restricted by the human, financial, and land resources, thereby limiting the genetic diversity it can conserve. The opposite is true for cryopreservation: the higher the number of accessions conserved, the lower the unit cost. Further, cryopreservation is more secure against unfavorable weather, vandalism, pests, and diseases. In a field collection, accessions are grown in a monoculture, making them particularly susceptible to pests and diseases. This vulnerability is accentuated by the fact that many accessions may not be adapted to the local environments of field genebanks. Local climate and other environmental conditions represent strong selection pressures on individuals in field genebanks and contribute to skewed genetic erosion in field collections. These problems can be mitigated to some extent by cryopreserving a core collection-a subset of accessions of a large germplasm collection chosen to represent the genetic variability of the entire collection (Frankel 1984) or by duplicating the collection in diverse eco-geographic sites, which makes conservation more expensive.

This study investigated coffee as a test case, but the results are relevant to other species that are difficult to conserve using the traditional method of seed drying and low-temperature storage. The underlying objective of the study was to assess the potential impact of the widespread adoption of cryopreservation for more species and in more genebanks. Over the past $15 \mathrm{yr}$, Bioversity and many of its partners have invested in the development and adoption of cryopreservation methodologies by developing, testing, and documenting protocols, training technicians and scientists, and supporting the acquisition of equipment for cryopreservation. Once adopted, cryopreservation is expected to result in improved conservation of difficult species in terms of (i) greater efficiency of conservation (lower costs and more efficient use of a complementary range of conservation methods); (ii) more effective and secure conservation (better viability over the long term, less overall loss of germplasm to pests, diseases and natural disasters, and maintenance of accession purity); and (iii) a wider range of diversity conserved (with a greater number of accessions conserved).

This study shows that the costs of cryopreservation should not be considered prohibitive to establishing safety duplicated cryo-preserved collections of coffee. If cryopreservation is adopted as a complement to field collections, either individual genebanks or those operating collaboratively will 
Table 9. Centro Agronómico Tropical de Investigación y Enseñanza (CATIE) field collection and cryo-collection. Present values (total and per accession costs in US\$) in fixed time periods at theoretical interest rates. Calculated on the basis of 1992 accessions for both field and cryo-collections.

\begin{tabular}{|c|c|c|c|c|c|c|c|}
\hline \multirow[t]{2}{*}{ Cost category } & \multirow[t]{2}{*}{ Rate of interest } & & \multicolumn{5}{|c|}{ Years } \\
\hline & & & 30 & 50 & 70 & 100 & 150 \\
\hline \multirow[t]{6}{*}{ Field collection } & $2 \%$ & Total & $60,70.68$ & 4326.74 & 3625.78 & 3154.69 & 2866.22 \\
\hline & & Per accession & 3.05 & 2.17 & 1.82 & 1.58 & 1.44 \\
\hline & $4 \%$ & Total & 7711.48 & 6207.33 & 5699.93 & 5441.63 & 5348.79 \\
\hline & & Per accession & 3.87 & 3.12 & 2.86 & 2.73 & 2.69 \\
\hline & $6 \%$ & Total & 9504.74 & 8300.49 & 7985.03 & 8164.78 & 7851.12 \\
\hline & & Per accession & 4.77 & 4.17 & 4.01 & 4.10 & 3.94 \\
\hline \multirow[t]{24}{*}{ Cryo-collection } & $2 \%$ & 300 & 1242.19 & 38.76 & 1.01 & 0.02 & 0.00 \\
\hline & & Per accession & 4.16 & 2.96 & 2.48 & 2.16 & 1.96 \\
\hline & & 500 & 1668.46 & 1189.16 & 996.51 & 867.03 & 787.75 \\
\hline & & Per accession & 3.33 & 2.37 & 1.99 & 1.73 & 1.57 \\
\hline & & 1000 & 2638.15 & 1880.28 & 1575.67 & 1370.94 & 1245.58 \\
\hline & & Per accession & 2.63 & 1.87 & 1.57 & 1.36 & 1.24 \\
\hline & & 2000 & 4817.60 & 3433.63 & 2877.36 & 2503.51 & 2274.59 \\
\hline & & Per accession & 2.41 & 1.72 & 1.44 & 1.25 & 1.14 \\
\hline & $4 \%$ & 300 & 1577.93 & 1270.15 & 1166.32 & 1113.47 & 1094.47 \\
\hline & & Per accession & 5.28 & 4.25 & 3.90 & 3.73 & 3.66 \\
\hline & & 500 & 2119.42 & 1706.02 & 1566.57 & 1495.57 & 1470.06 \\
\hline & & Per accession & 4.23 & 3.40 & 3.12 & 2.98 & 2.93 \\
\hline & & 1000 & 3351.20 & 2697.54 & 2477.04 & 2364.78 & 2324.44 \\
\hline & & Per accession & 0.06 & 2.69 & 2.47 & 2.35 & 2.31 \\
\hline & & 2000 & 6119.70 & 4926.04 & 4523.37 & 4318.39 & 4244.71 \\
\hline & & Per accession & 3.06 & 2.46 & 2.26 & 2.16 & 2.12 \\
\hline & $6 \%$ & 300 & 1944.87 & 1698.45 & 1633.90 & 1670.68 & 1606.50 \\
\hline & & Per accession & 6.51 & 5.69 & 5.47 & 5.59 & 5.38 \\
\hline & & 500 & 2612.28 & 2281.30 & 2194.60 & 2244.00 & 2157.80 \\
\hline & & Per accession & 5.21 & 4.55 & 4.38 & 4.47 & 4.30 \\
\hline & & 1000 & 4130.50 & 3607.17 & 3470.08 & 3548.19 & 3411.89 \\
\hline & & Per accession & 4.11 & 3.59 & 3.45 & 3.53 & 3.40 \\
\hline & & 2000 & 7542.81 & 6587.13 & 6336.79 & 6479.43 & 6230.53 \\
\hline & & Per accession & 3.77 & 3.29 & 3.17 & 3.24 & 3.11 \\
\hline
\end{tabular}

Equipment Costs

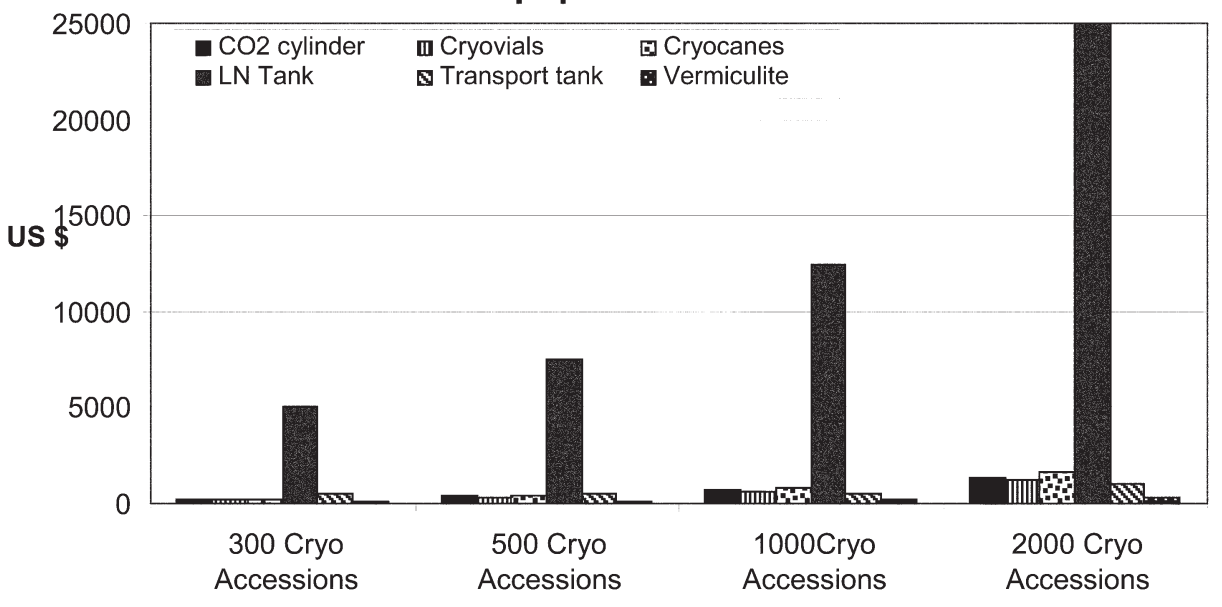

Number of Accessions need to add the costs of cryopreservation to their current costs of field conservation. Alternatively, they could reduce their field collections and replace some with cryo-preserved collections. Further studies are needed to establish the optimal balance between cryopreservation and field collection to ensure the longterm security of coffee genetic resources in a cost-efficient way.

Given the importance of genetic diversity to coffee producers-many of whom are small farmers depending on coffee for their livelihoodspolicymakers from coffee-producing countries should lay the groundwork for establishing additional cryo-collections to ensure the future health of the

Figure 6. Major equipment costs per accession. 
crop. A regional or global cryopreserved collection could be established for coffee germplasm (as has been done for other crops such as Musa) in which the costs of cryopreservation and the benefits derived from germplasm conservation could be shared among partner countries.

This study raised questions about the application of the cryopreservation protocol to coffee, since a significant percentage of the cryo-preserved germplasm was lost as a result of infection in the thawing and regeneration processes. To ensure that an adequate protocol is available, additional research should be conducted and the results made available to the coffee conservation community. But the study also has broader implications for policymakers and researchers, since many of the world's most important crops cannot be conserved ex situ using conventional methodologies. The costs of conservation in field genebanks are likely to be greater for short-lived crops like annual vegetables since they require more maintenance and more frequent regenerations in the field. Under these conditions, cryopreservation is likely to be an even more cost-effective conservation option.

\section{Acknowledgments}

The authors would like to thank the following people for their advice and for providing information on the costs of conservation: Bonwoo Koo (University of Waterloo, Canada), Brian Wright (University of California, Berkley), Mohammad Bare (FAO), J.F. Trontin (AFOCEL, France), and Dave Ellis (USDA, Fort Collins, CO). We also thank Hope Traficanti (USA) for the English language editing of the manuscript.

\section{References}

Anthony, F. 1992. Les ressources génétiques des caféiers: Collecte, gestion d'un conservatoire et évaluation de la diversité génétique. Collection Travaux \& Documents Microfichés 81, ORSTOM Paris.

Anthony, A., C. Astorga, J. Avendaño, and M.E. Dulloo. 2007. Conservation of coffee genetic resources in the CATIE field genebank. p. 23-34. In F. Engelmann et al. (ed.) Complementary strategies for ex situ conservation of coffee (Coffea arabica L.) genetic resources: A case study in CATIE, Costa Rica. Bioversity International, Rome.

Berthaud, J., and A. Charrier. 1988. Genetic resources of Coffea. p. 1-42. In R.J. Clarke and R. Macrae (ed.) Coffee agronomy. Elsevier, Amsterdam.

Bertrand, B., R. Cattet, J. Díaz, C. Núñez, N. Marbán, and F. Anthony. 1993. Descripción y estructuración de los cafetos silvestres colectados en Etiopía por el ORSTOM. Consecuencias por el mejoramiento. p. 18. In Proc. of the XVI Symp. on Latin-American coffee cultivation, Vol. 1, Managua. 25-29 Oct. 1993. IICA/PROMECAFE Guatemala City.

Bettencourt, E., and J. Konopka. 1988. Directory of germplasm collections. 5. II. Industrial crops. Beet, coffee, oil palm, cotton and rubber. IBPGR, Rome.

Burstin, J., M. Lefort, M. Mitteau, A. Sontot, and J. Guiard. 1997. Towards the assessment of the cost of genebanks management: Conservation, regeneration, and characterization. Plant Var. Seeds 10:163-172.
Charrier, A., and J. Berthaud. 1985. Botanical classification of coffee. p. 1-347. In M.N. Clifford and K. Willson (ed.) Coffee botany, biochemistry, and production of beans and beverage. Croom Helm, London.

Davis, A.P., R. Govaerts, D.M. Bridson, and P. Stoffelen. 2006. An annotated taxonomic conspectus of the genus Coffea (Rubiaceae). Bot. J. Linn. Soc. 152:465-512.

Dulloo, M.E. 1998. Diversity and conservation of wild Coffea germplasm in the Mascarene Islands. Ph.D. thesis. Univ. of Birmingham, UK.

Dulloo, M.E., A. Charrier, S. Dussert, F. Anthony, S. Tesfaye, J.J. Rakotomalala, C. Agwanda, and N. Legnate. 2001. Conservation of coffee genetic resources: Constraints and opportunities. In Proc. of 19th World Colloquium on Coffee Science, ASIC, Trieste, Italy. May 2001. Association Scientifique Internationale du Café, Paris.

Dulloo, M.E., L. Guarino, F. Engelmann, N. Maxted, H.J. Newbury, F. Attere, and B.V. Ford Lloyd. 1998. Complementary conservation strategies for the genus Coffea: A case study of Mascarene Coffea species. Genet. Resour. Crop Evol. 45:565-579.

Dussert, S., N. Chabrillange, F. Anthony, F. Engelmann, C. Recalt, and S. Hamon. 1997a. Variability in storage response within a coffee (Coffea spp.) core collection under slow growth conditions. Plant Cell Rep. 16:344-348.

Dussert, S., N. Chabrillange, F. Engelmann, F. Anthony, and S. Hamon. 1997b. Cryopreservation of coffee (Coffea arabica L.) seeds: Importance of the precooling temperature. CryoLetters 18:269-276.

Dussert, S., N. Chabrillange, F. Engelmann, F. Anthony, J. Louarn, and S. Hamon. 1998. Cryopreservation of seeds of four coffee species (Coffea arabica, C. costatifructa, C. racemosa and C. sessiliflora): Importance of water content and cooling rate. Seed Sci. Res. 8:9-15.

Dussert, S., N. Chabrillange, J.L. Montillet, J.P. Agnel, F. Engelmann, and M. Noirot. 2003a. Basis of coffee seed sensitivity to liquid nitrogen exposure: Oxidative stress or imbibitional damage? Physiol. Plant. 119:534-543.

Dussert, S., N. Chabrillange, G. Rocquelin, F. Engelmann, M. Lopez, and S. Hamon. 2001. Tolerance of coffee (Coffea spp.) seeds to ultra-low temperature exposure in relation to calorimetric properties of tissue water, lipid composition and cooling procedure. Physiol. Plant. 112:495-504.

Dussert, S., N. Chabrillange, N. Vásquez, F. Engelmann, F. Anthony, and A. Guyot. 2000. Beneficial effect of post-thawing osmoconditioning on the recovery of cryopreserved coffee (Coffea arabica L.) seeds. CryoLetters 21:47-52.

Dussert, S., F. Engelmann, N. Chabrillange, F. Anthony, M. Noirot, and S. Hamon. 1997c. In vitro conservation of coffee (Coffea spp.) germplasm. p. 287-305. In M.K. Razdan and E.C. Cocking (ed.) Conservation of plant genetic resources in vitro. Vol. 1. Science Publ., Enfield, NH.

Dussert, S., and F. Engelmann. 2006. New determinants of coffee (Coffea arabica L.) seed tolerance to liquid nitrogen exposure. CryoLetters 27:169-178.

Dussert, S., F. Engelmann, and M. Noirot. 2003b. Development of probabilistic tools to assist in the establishment and management of cryopreserved plant germplasm collections. CryoLetters 24:149-160.

Eira, M.T.S., V.S. Ribeiro, and G.F. Bartholo. 2007. Longevidade de sementes de cultivares de Catuaí (Coffea arabica L.) em Banco de germoplasma. In Simpósio de Pesquisa dos 
Cafés do Brasil, 5, Águas de Lindóia, Brasil. 7-11 May 2001. EMBRAPA, Brasilia DF, Brazil.

Eira, M.T.S., E.A.A. Silva, R.D. Castro, S. Dussert, C. Walters, J.D. Bewley, and H.W.M. Hilhorst. 2006. Coffee seed physiology. Brazil. J. Plant Physiol. 18:149-163.

Ellis, R.H., T.S. Hong, and E.H. Roberts. 1990. An intermediate category of seed storage behaviour? I. Coffee. J. Exp. Bot. 41:1167-1174.

Engelmann, F. 1991. In vitro conservation of tropical plant germplasm: A review. Euphytica 57:227-243.

Engelmann, F. 1997. In vitro conservation methods. p. 119-162. In B.V. Ford Lloyd et al. (ed.) Biotechnology and plant genetic resources: Conservation and use. CABI, Wallingford, UK.

Engelmann, F. 2004. Plant cryopreservation: Progress and prospects. In Vitro Cell. Dev. Biol. Plant 40:427-433.

Engelmann, F., and J.M. Engels. 2002. Technologies and strategies for ex situ conservation. p. 89-103. In J.M. Engels et al. (ed.) Managing plant genetic diversity. IPGRI, Rome and CABI, Wallingford, UK.

Engelmann, F., and H. Takagi (ed.). 2000. Cryopreservation of tropical plant germplasm-Current research progress and applications. Japan Int. Res. Cent. for Agric. Sci., Tsukuba, Japan/IPGRI, Rome.

Epperson, J.E., D.H. Pachico, and C.L. Guevara. 1997. A cost analysis of maintaining cassava plant genetic resources. Crop Sci. 37:1641-1649.

FAO. 1998. The state of the world's plant genetic resources for food and agriculture. FAO, Rome.

Frankel, O.H. 1984. Genetic perspectives of germplasm conservation. p. 161-170. In W. Arber et al. (ed.) Genetic manipulation: Impact on man and society. Cambridge Univ. Press, Cambridge, UK.

Frison, E., and J. Serwinski (ed.). 1995. Directory of European institutions holding plant genetic resources. 4th ed. Vol. 1 and 2. IPGRI, Rome.

Gole, T.W., M. Denich, D. Teketay, and P.L. Vlek. 2002. Human impacts on the Coffea arabica genepool in Ethiopia and the need for its in situ conservation. p. 237-247. In J.M. Engels et al. (ed.) Managing plant genetic diversity. IPGRI, Rome; CABI, Wallingford, UK.

Guillaumet, J.-L., and F. Hallé. 1978. Echantillonnage du matériel récolté en Ethiopie. Bulletin IFCC 14:13-18.

Hawkes, J., N. Maxted, and B.V. Ford Lloyd. 2001. The ex situ conservation of plant genetic resources. Kluwer Academic Publishers, Dordrecht, the Netherlands.

Hein, L., and F. Gatzweiler. 2006. The economic value of coffee (Coffea arabica) genetic resources. Ecol. Econ. 60:176-185.

Hong, T.S., and R.H. Ellis. 1995. Interspecific variation in seed storage behaviour within two genera, Coffea and Citrus. Seed Sci. Technol. 23:165-181.

Hummer, K., and B.M. Reed. 1999. Establishment and operation of a temperate clonal field genebank. p. 29-31. In F. Engelmann (ed.) Management of Field and In Vitro Germplasm Collection: Proc. of a Consultation Meeting, CIAT, Cali, Colombia. 15-20 Jan. 1996. CIAT, Cali/IPGRI, Rome.

ICO. 2008. International Coffee Organization. Available at http:// www.ico.org/new_historical.asp (verified 7 Sept. 2009). ICO, London.

Jarret, R.L., and W.J. Florkowski. 1990. In vitro active vs. field genebank maintenance of sweet potato germplasm: Major cost considerations. HortScience 25:141-146.

Koo, B., P.G. Pardey, and B.D. Wright. 2002. Endowing future harvests: The long-term costs of conserving genetic resources at the CGIAR centres. IPGRI, Rome.

Koo, B., P.G. Pardey, and B.D. Wright. 2003. Conserving genetic resources for agriculture: Counting the cost. Brief 6. IFPRI, Washington, DC.

Meyer, F.G., L.M. Fernie, R.L. Narasimhaswamy, L.C. Monaco, and D.J. Greathead. 1968. FAO Coffee Mission to Ethiopia 1964-1965. FAO, Rome.

Pardey, P.G., B. Koo, B.D. Wright, M.E. Van Dusen, B. Skovmand, and S. Taba. 2001. Costing the conservation of genetic resources: CIMMYT's ex situ maize and wheat collection. Crop Sci. 41:1286-1299.

Reed, B., F. Engelmann, M.E. Dulloo, and J.M. Engels. 2004. Technical guidelines on management of field and in vitro germplasm collections. Handbook for Genebanks 7. IPGRI, Rome.

Saxena, S., V. Chandak, S.B. Ghosh, R. Sinha, N. Jain, and A.K. Gupta. 2002. Cost of conservation of agrobiodiversity. NBPGR and Indian Institute of Management, New Delhi.

UNCED. 1992. Convention on Biological Diversity. United Nations Conference on Environment and Development, Geneva.

Vásquez, N., K. Salazar, F. Anthony, N. Chabrillange, F. Engelmann, and S. Dussert. 2005. Variability in response of seeds to liquid nitrogen exposure in wild coffee (Coffea arabica L.). Seed Sci. Technol. 33:293-301.

Vega, F.E., A.W. Ebert, and R. Ming. 2008. Coffee germplasm resources, genomics and breeding. Plant Breed. 30:415-447.

Virchow, D. 1999. Spending on conservation of plant genetic resources for food and agriculture: How much and how efficient? ZEF discussion papers on development policy 16, Cent. for Dev. Res., Bonn.

Virchow, D. 2003. Current expenditures on crop genetic resources activities. p. 71-75. In D. Virchow (ed.) Efficient conservation of crop genetic diversity. Springer, Berlin. 